\title{
Formation and Surface Structural Features of Crystalline Ceramic Nanocomposite Coatings on Aluminium Using Lithium Sulphate with Silicate Additive
}

\author{
M. Mubarak Ali • V. Raj
}

Received: 28 June 2013/Revised: 28 October 2013/Published online: 25 April 2014

(C) The Chinese Society for Metals and Springer-Verlag Berlin Heidelberg 2014

\begin{abstract}
We have synthesized a series of the ceramic coatings by anodization of aluminium using lithium sulphate and sodium silicate additive. Our experiments show that the present coatings are nanocomposites in nature, consisting of a mixture of nanocrystalline alumina, silica, aluminium silicate and mullite; the formation of alumina was similar to conventional anodizing technology, while the formation of mullite was attributed to an addition of sodium silicate. The microhardness of the coatings progressively increased with the increasing current density up to $0.2 \mathrm{~A} / \mathrm{cm}^{2}$, which could mainly be attributed to the decrease of porosity in the interfacial region of the oxides up to the range. From the performance of the coatings against corrosion (Tafel/Nyquist plots), it was inferred that the coatings fabricated by lithium sulphatesodium silicate bath have enhanced corrosion resistance $\left(R_{\mathrm{p}}=3.12 \mathrm{k} \Omega\right)$, as well as better microhardness value than that of the lithium sulphate bath alone $\left(R_{\mathrm{p}}=660.96 \Omega\right)$ which confirm the perception that the silica particles included in the anodized alumina matrices randomly. Presence of $\mathrm{Al}, \mathrm{Si}$ and $\mathrm{O}$ indicated that the electrolyte components had been intensively incorporated into the coatings.
\end{abstract}

KEY WORDS: Anodization; Nanocomposite; Ceramic; Lithium sulphate

\section{Introduction}

Ceramic coatings have been utilized in surface engineering applications for over the two decades [1]. Recent investigations have concentrated on the nanostructured ceramic materials for improving the performance of macro [2] and micro-scale [3] mechanical systems. Mixing two or more

Available online at http://link.springer.com/journal/40195

M. Mubarak Ali $(\bowtie)$

Department of Chemistry, Chikkaiah Naicker College,

Erode 638 004, Tamil Nadu, India

e-mail: masterscience2003@yahoo.co.in

M. Mubarak Ali · V. Raj

Advanced Materials Research Laboratory, Department of Chemistry, Periyar University, Salem 636 002, Tamil Nadu, India

e-mail: alaguraj2@rediffmail.com phases on the nanometer scale has been reported to lead the significant enhancement in coating hardness [4] and toughness [5] beyond the intrinsic properties of the constituent phases.

Aluminium is selected for its optimal combination of the physical and mechanical properties [6] for various industrial applications. One major advantage is that lightweight metal components lead to an overall reduced weight and thus reduced energy consumption. Another advantage, which may be just as important from an environmental point of view, is the fact that aluminium components can be recycled with relatively low-energy demands [7]. Although many light weight metals can be anodized with various electrolytes, aluminium anodizing is the most popular and widely used in various commercial and military applications [8].

Usually, sulphate salts are widely used as additives in anodization process to fabricate thick and hard coatings on aluminium as seen from the past literature. But there is no 
report available, or very less in fabrication, surface characterization and corrosion behaviour of the thick and hard coatings fabricated from lithium sulphate alone and with silicate additives except magnesium sulphate and lithium sulphate with zirconium silicate which is reported by us recently $[9,10]$. In this report, it is aimed to establish the formation, surface characterization, mechanical evaluation (Vickers microhardness) and corrosion resistance performance of the coatings fabricated from lithium sulphatesodium silicate bath.

Usually the coatings were fabricated in alkaline electrolyte with silicate additive by plasma electrolytic oxidation and have been reported in plenty of articles [11]. In olden days, the sulphate salts were used to reduce the dissolution process in anodization baths [12]. It is significant to investigate further the influence of experimental parameters which play an important role in determining the microstructure of the coatings and will eventually determine the performances of the devices. To enhance this, further knowledge may require on the coating formation, its growth and the influence of various anodizing parameters, more specifically the current density. The present study focuses not only to fabricate the coatings from our newly modified electrolyte, but also to improve the corrosion resistance of aluminium. In this paper, we will discuss the influence of current density and other anodization parameters on the microstructure, phase composition, microhardness testing evaluation and corrosion resistance of the coatings to optimize the fabrication process and finally improve their properties.

\section{Experimental}

Rectangular specimens of aluminium $(5 \mathrm{~cm} \times 2 \mathrm{~cm} \times$ $0.1 \mathrm{~cm}$ ) were used as substrates. All samples were prepared from the same aluminium sheet $(99.9 \% \mathrm{Al})$. First, the specimens were degreased with acetone, alkali cleaned in 5\% $\mathrm{NaOH}$ solution at $30{ }^{\circ} \mathrm{C}$ for $2 \mathrm{~min}$, followed by desmutting in $25 \% \mathrm{HNO}_{3}$ solution at $30{ }^{\circ} \mathrm{C}$ for $1 \mathrm{~min}$. Then, the pretreated and pre-weighed $\left(w_{1}\right)$ aluminium specimens were connected to positive terminal (anode) and insoluble lead cathode $(10 \mathrm{~cm} \times 3 \mathrm{~cm} \times 0.3 \mathrm{~cm})$ to the negative terminal of the regulated DC power supply (Aplab Model: 0-5 A/ $30 \mathrm{~V}$ and $0-1 \mathrm{~A} / 120 \mathrm{~V})$. Anodization of aluminium was carried out under galvanostatic conditions using lithium sulphate with and without sodium silicate additive. After anodizing treatment, the specimens were washed with running water and rinsed with deionised water, dried $\left(\mathrm{N}_{2}\right.$ gas) and weighed $\left(w_{2}\right)$. The working surface of the specimen was $1 \mathrm{~cm}^{2}$, and the rest of the surface was insulated with an epoxy resin. The surface morphology, the nanostructures and the elemental compositions of the coatings were analysed by field emission scanning electron microscope, atomic force microscope and energy-dispersive X-ray spectroscope. All the samples tested by FESEM were sputtered with thin platinum film $(30 \mathrm{~nm})$ to prevent the surface charging effects. The crystallographic characteristics of the coatings were investigated by powder X-ray diffractometer working on $\mathrm{Cu} K_{\alpha}$ radiation. The microhardness was measured by a Vickers microhardness indenter. Various applied loads were selected to measure the microhardness measurements such as $0.25,0.50,1.0,2.0$ and $3.0 \mathrm{~N}$ [13].

Thickness of the coatings was measured non-destructively using PosiTector 6000 of eddy current thickness tester. Growth rate of the coating was calculated from the thickness values, i.e., the thickness values were divided by the anodizing time $(\mu \mathrm{m} / \mathrm{min})$. The coating ratio was obtained using method in Ref. [9]. The coating was stripped off and weighed $\left(w_{3}\right)$ to find out the exact amount of $\mathrm{Al}$ dissolved. The stripping was done by immersing the anodized aluminium in $30 \mathrm{~mol} / \mathrm{L}$ phosphoric acid and $25 \mathrm{~g} / \mathrm{L}$ chromic acid solution at $60{ }^{\circ} \mathrm{C}$ up to the complete removal of the coating. The actual weight of the coating was obtained from $w_{2}$ to $w_{3}$. The coating ratio $(R)$ was obtained by using the formula given below

$R=\left(w_{2}-w_{3}\right) /\left(w_{1}-w_{3}\right)$,

where $w_{1}$ and $w_{2}$ are the weights of the specimen before and after anodization and $w_{3}$ is the weight of the specimen after stripping off the coating.

Tafel polarization and AC impedance studies were carried out using electrochemical workstation (CHI 760, $\mathrm{CH}$ Instruments, USA) to evaluate the coatings performance against corrosion. The Tafel polarization studies were carried out in a glass cell using a typical three-electrode system consisting of anodized $\mathrm{Al}$ as working electrode, platinum as counter electrode and the saturated calomel electrode (SCE) as reference electrode along with Agar-Agar- $\mathrm{KCl}$ salt bridge in all experiments (electrolyte: $3.5 \% \mathrm{NaCl}$ solution) under free-air conditions at room temperature $\left[(28 \pm 1){ }^{\circ} \mathrm{C}\right]$. The tip of the reference electrode was positioned very close to the surface of the working electrodes by the use of a fine Luggin capillary to minimize ohmic potential drop. The experimental conditions for the polarization measurements are described elsewhere [14]. The corrosion potential $\left(E_{\text {corr }}\right)$, the corrosion current density $\left(i_{\text {corr }}\right)$ and the polarization resistance $\left(R_{\mathrm{p}}\right)$ were deduced from the Tafel and impedance plots.

\section{Results and Discussion}

\subsection{Influence of the Concentration of Lithium Sulphate}

In this report, we fabricated the coatings on aluminium by the anodization technique using lithium sulphate 
electrolyte with sodium silicate additive. From these observations, it can be seen that the coatings formed from $7.5 \mathrm{~g} / \mathrm{L}$ lithium sulphate has the maximum thickness $(55 \mu \mathrm{m})$, the growth rate $(1.83 \mu \mathrm{m} / \mathrm{min})$ and the coating ratio (1.7). When the concentration was below $5 \mathrm{~g} / \mathrm{L}$, no uniform coating was formed and dissolution of the metal itself was occurred. Likewise, when the concentration exceeded above $15 \mathrm{~g} / \mathrm{L}$, the dissolution of the coating takes place vigorously. Even if we change this concentration slightly, it would cause unfavourable coating formation. So, $7.5 \mathrm{~g} / \mathrm{L}$ concentration was taken as the optimum concentration for the formation of the coatings with maximum thickness and corrosion resistance. At low concentration (around $5 \mathrm{~g} / \mathrm{L}$ and above it) of lithium sulphate, the coating containing a number of micropores and small quantity of $\mathrm{SO}_{4}{ }^{2-}$ was formed.

\subsection{Influence of Concentration of Sodium Silicate}

When sodium silicate was added to $7.5 \mathrm{~g} / \mathrm{L}$ lithium sulphate, no uniform and adherent coating was formed on the aluminium surface. In addition to this, the substrate gets corroded itself. Because the above optimization of the process parameters would suit to lithium sulphate only, but the addition of the sodium silicate may modify the nature of the electrolyte to anodize. So an effort was taken to optimize the lithium sulphate and sodium silicate bath again. The experimental observations illustrate the variation in the thickness and the growth rate of the coatings anodized for $30 \mathrm{~min}$ in $35 \mathrm{~g} / \mathrm{L}$ lithium sulphate containing different concentrations of the sodium silicate $(0.02-0.1$ $\mathrm{g} / \mathrm{L})$ at constant current density $\left(0.2 \mathrm{~A} / \mathrm{cm}^{2}\right)$ and the temperature $\left[(10 \pm 1){ }^{\circ} \mathrm{C}\right]$. It can be seen that the coating thickness increases with the increasing concentration up to $0.08 \mathrm{~g} / \mathrm{L}$ sodium silicate. So, the optimum concentration of the lithium sulphate was found to be $35 \mathrm{~g} / \mathrm{L}$ in this case. Feldman et al. [15] have noticed in the zirconia-silica system that a large addition of silica yields films having an amorphous structure with low density. The quality of the coating can be controlled by changing the compositions of electrolyte and nature of alloy [16], the temperature, treatment time, applied voltage [17], anodic current density and the ratio of cathode to the anode size, etc. [18] The dissociation of the sodium silicate is depicted in the below reactions (reaction 2). Mullite is formed (reaction 6) due to the combination of silica and alumina. We proposed the following reactions (2-6) to explain ionic mechanism of the process in this case.

$$
\begin{aligned}
& \mathrm{Na}_{2} \mathrm{SiO}_{3} \rightarrow 2 \mathrm{Na}^{+}+\mathrm{SiO}_{3}^{2-}, \\
& 2 \mathrm{Al}^{3+}+3 \mathrm{SiO}_{3}^{2-} \rightarrow \mathrm{Al}_{2}\left(\mathrm{SiO}_{3}\right)_{3}, \\
& 2 \mathrm{Al}^{3+}+3 \mathrm{O}^{2-} \rightarrow \mathrm{Al}_{2} \mathrm{O}_{3},
\end{aligned}
$$

$\mathrm{SiO}_{3}^{2-} \rightarrow \mathrm{SiO}_{2}+\mathrm{O}^{2-}$,

$\mathrm{Al}_{2} \mathrm{O}_{3}+\mathrm{SiO}_{2} \rightarrow \mathrm{Al}_{2} \mathrm{O}_{3} \cdot \mathrm{SiO}_{2}$.

\subsection{Influence of Treatment Time}

\subsubsection{On Voltage-Time Response}

The voltage-time response during anodizing at various current densities from 0.1 to $0.25 \mathrm{~A} / \mathrm{cm}^{2}$ in $7.5 \mathrm{~g} / \mathrm{L}$ lithium sulphate electrolyte was recorded and presented in Fig. 1. It can be observed from the Fig. 1 that as the treatment time increases, the anodic potential rises very rapidly at the beginning and reaches the maximum potential $\left(V_{\max }\right)$ within $5 \mathrm{~s}$. The potential maximum $\left(V_{\max }\right)$ increases with the increase in applied current density. The sharp rise in potential with time is due to the formation of the barrier oxide layer. In order to overcome the resistance offered by the barrier layer, very high voltage is required to penetrate the coating. After reaching the maximum, steady-state potential is arrived and hence there is no predominant increase in potential for the rest of the anodizing period. During anodizing in lithium sulphate electrolyte alone $(7.5 \mathrm{~g} / \mathrm{L})$ at all current densities $(0.1-0.25$ $\mathrm{A} / \mathrm{cm}^{2}$ ) (Fig. 1a), the voltage rises linearly with time. Besides, because of the porous structure and micro-cracks of the coating, the liberated gas $\left(\mathrm{O}_{2}\right)$ on the anode surface could form continuous or discontinuous vapour envelopes consequently, which would also take up a certain voltage drop.

\subsubsection{On Thickness and Growth Rate}

In the present study, attention was directed towards the variation of the thickness and the growth rate with respect to the time. The thickness increases gradually from $22 \mu \mathrm{m}$ (15 $\mathrm{min}$ ) to $65 \mu \mathrm{m}$ (30 $\mathrm{min})$, as well as the growth rate increases with time up to $30 \mathrm{~min}$, after that it decreases.

The influence of the treatment time on the thickness and the growth rate of the coatings formed from lithium sulphate-sodium silicate bath have been studied. It can be seen that there is a gradual increase in the coatings thickness with treatment time. Since, the dissolution predominates over formation, the thickness decreases after $30 \mathrm{~min}$. So, 30 min was chosen as optimum time for formation of the coatings with maximum thickness. The dimension of the pores also increases with increasing the time and the surface of the coating become looser.

Usually, the barrier-type anodic films are thin $(<1 \mu \mathrm{m})$, while the thickness of the porous layer varies from 1 to $300 \mu \mathrm{m}$ [18]. The barrier-type films consist of an inner oxide (adjacent to oxide/metal interface) of high-purity alumina and an outer oxide layer (adjacent to the electrolyte/oxide interface) which may contain incorporated anions from the electrolyte. The growth of the oxide occurs mainly at the metal/oxide interface due to inward migration 

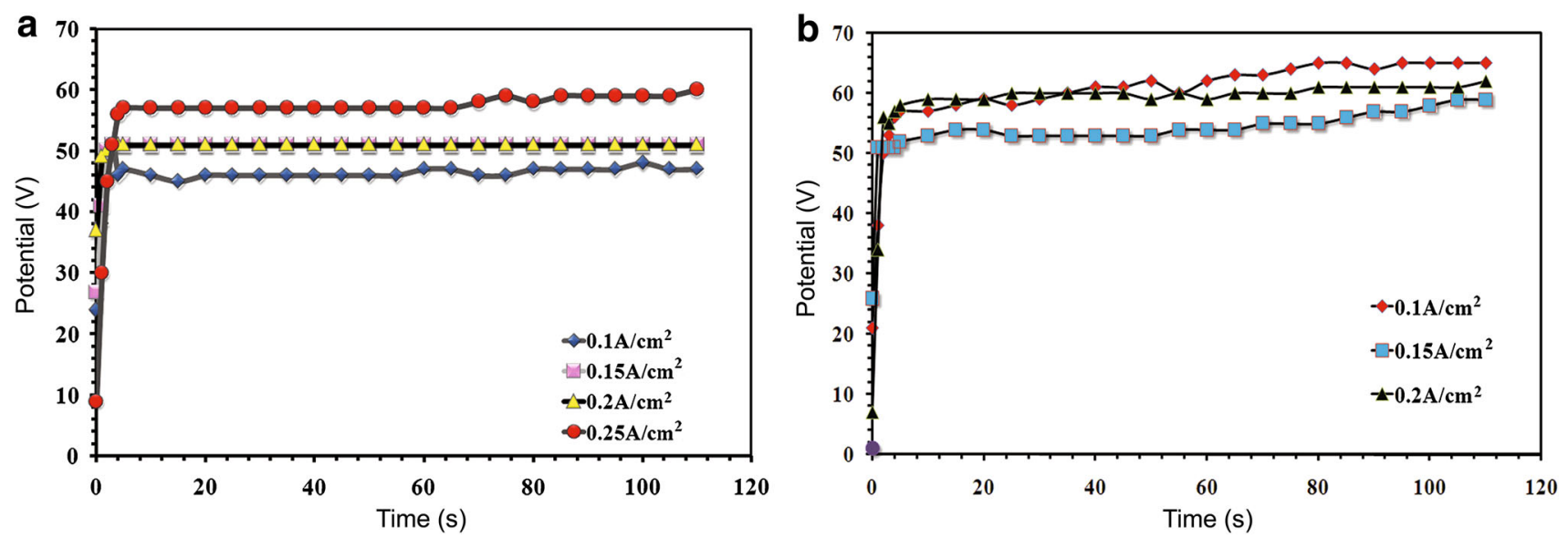

Fig. 1 Voltage-time response of the coatings obtained from lithium sulphate a, lithium sulphate-sodium silicate b baths

of $\mathrm{O}^{2-}$ ions across the barrier layer. Simultaneously, $\mathrm{Al}^{3+}$ ions migrate outward to the electrolyte [19].

\subsection{Influence of Current Density}

\subsubsection{On Thickness and Growth Rate}

The influence of the current density $\left(0.1-0.25 \mathrm{~A} / \mathrm{cm}^{2}\right)$ on the thickness and the growth rate of the coatings formed from lithium sulphate bath/lithium sulphate-sodium silicate bath was investigated. From the data, it is observed that the current density has strong influence on the properties of the coatings. The advantages of the constant current density process have been recognized over the years [20]. Unfortunately, these strengths were not addressed explicitly in scientific description with fundamental understanding. In the constant current density, the growth rate of the coating is almost constant during the anodizing process within a specified period, because the growth rate of the coating is determined by the current density rather than cell voltage [8]. The $\mathrm{Al}^{3+}$ ions are much less mobile than $\mathrm{H}^{+}$and under the field of action; they are transferred much less easily than $\mathrm{H}^{+}$. Therefore, inside the diffusion layer, the concentration of $\mathrm{Al}^{3+}$ is generally much higher than that of $\mathrm{H}^{+}$. During the very early stages of pore formation, $\mathrm{Al}^{3+}$ ions are accumulated in that layer.

Since, the coating thickness is closely related to the anodic current density [21], the thickness increased with current density up to $0.2 \mathrm{~A} / \mathrm{cm}^{2}$ at $(10 \pm 1){ }^{\circ} \mathrm{C}$ for $30 \mathrm{~min}$. The anodic product resulting from aluminium dissolution has been reported [22] to be alumina, and therefore, the rest potential will probably be defined by the potentials for the aluminium dissolution, alumina formation and the hydrogen evolution reactions. The following proposed chemical reactions (7-11) may dominate the aluminium anodization [23].
$\mathrm{Al}^{3+}$ ions formed and distributed at the metal/oxide interface in the oxide layer near the oxide/metal interface:

$\mathrm{Al} \rightarrow \mathrm{Al}^{3+}+3 \mathrm{e}^{-}$.

The electrolysis of water (a water-splitting reaction) occurs at the pore bottom near the electrolyte/oxide interface [24]:

$2 \mathrm{H}_{2} \mathrm{O} \rightarrow 2 \mathrm{O}^{2-}+4 \mathrm{H}^{+}$.

Due to the electric field, the $\mathrm{O}^{2-}$ ions migrate within the barrier layer from the electrolyte/oxide interface to the oxide/metal interface, and react with the $\mathrm{Al}^{3+}$ ions thereby, form $\mathrm{Al}_{2} \mathrm{O}_{3}$ :

$2 \mathrm{Al}^{3+}+3 \mathrm{O}_{2} \rightarrow \mathrm{Al}_{2} \mathrm{O}_{3}$.

There is electric field to enhance oxide dissolution at the electrolyte/oxide interface:

$\mathrm{Al}_{2} \mathrm{O}_{3}+6 \mathrm{H}^{+} \rightarrow 2 \mathrm{Al}^{3+}$ (aq.) $+3 \mathrm{H}_{2} \mathrm{O}$.

According to Ref. [25], the $\mathrm{SO}_{3}$ content of the film increases with the current density. Therefore, it can be said that the stronger electric field at the higher current density causes the increase of $\mathrm{SO}_{3}$ content of the film.

$\mathrm{Li}_{2} \mathrm{SO}_{4}+2 \mathrm{H}_{2} \mathrm{O} \rightarrow 2 \mathrm{Li}^{+}+\mathrm{SO}_{3}+\mathrm{O}^{2-}+\mathrm{H}_{2}+2 \mathrm{OH}^{-}$.

Both the thickness and the growth rate increase with the increasing current density and maximum thickness values were obtained at $0.2 \mathrm{~A} / \mathrm{cm}^{2}$ after that, the properties begin to decrease. The increase in the thickness and the growth rate with the increase in current density is according to Faraday's law, since the formation of the coatings depends on the applied current density. At very high current density $\left(>0.2 \mathrm{~A} / \mathrm{cm}^{2}\right)$, the dissolution of the coatings overpowers its formation. So, the growth rate and hence the thickness of the coatings decreases at high current densities. Since, 
the selection of the current density is important parameter in deciding morphology, composition and mechanical characterization; the coatings were formed at various current densities $\left(0.1-0.2 \mathrm{~A} / \mathrm{cm}^{2}\right)$ to optimize the anodization process. The maximum thickness and the growth rate of the coatings formed from lithium sulphatesodium silicate bath obtained at $0.2 \mathrm{~A} / \mathrm{cm}^{2}$ are $163 \mu \mathrm{m}$ and $5.43 \mu \mathrm{m} / \mathrm{min}$, respectively, for $30 \mathrm{~min}$ at $10{ }^{\circ} \mathrm{C}$.

\subsubsection{On Microhardness}

The microhardness was measured for the specimens obtained at all current densities $\left(0.1-0.25 \mathrm{~A} / \mathrm{cm}^{2}\right)$ by Vickers microhardness tester. The microhardness of the anodized specimens progressively varied with current density from 0.1 to $0.25 \mathrm{~A} / \mathrm{cm}^{2}$ at constant applied load of $0.25 \mathrm{~N}$ and for other loads such as 0.50, 1.0, 2.0 and $3.0 \mathrm{~N}$ also measured in a similar way. Figure 2 shows the effect of current density on the microhardness of the coatings obtained from lithium sulphate and lithium sulphatesodium silicate baths. From that it is observed that the microhardness increases with current density up to 0.2 $\mathrm{A} / \mathrm{cm}^{2}$ and then decreases only in the case of lithium sulphate bath. The variation of the microhardness with applied load was also observed [lithium sulphate bath: $290 \mathrm{HV}$ $(0.25 \mathrm{~N}) ; 278 \mathrm{HV}(0.50 \mathrm{~N}) ; 268 \mathrm{HV}(1.0 \mathrm{~N}) ; 247 \mathrm{HV}$ $(2.0 \mathrm{~N}) ; 245 \mathrm{HV}(3.0 \mathrm{~N})$ ]. Yang et al. [26] have found that the microhardness of the coatings fabricated at low current density is higher than that of the coatings deposited at high current density. Increasing current density for a certain substrate composition leads to an increase in the layer thickness, voltage, electrical field strength and consequently the liberation of enormous heat. These effects can generate larger gradients of the electrolyte temperature and the composition along the deeper pore walls that leads to oxide dissolution and adsorption of sulphate anions on the pore walls [27].

This trend is different significantly from lithium sulphate-sodium silicate bath in which the coatings could not fabricate beyond $0.2 \mathrm{~A} / \mathrm{cm}^{2}$. At the same time, the coatings fabricated at $0.2 \mathrm{~A} / \mathrm{cm}^{2}$ have highest microhardness (304.66 HV) among other cases. The variation in applied load from 0.025 to $3.0 \mathrm{~N}$ influencing the microhardness of the coatings (from 304.66 to $250.68 \mathrm{HV}$ ) as observed from the experiments. The depth profile with increasing applied load was also monitored and the maximum indent penetration depth was observed for $3.0 \mathrm{~N}$ was $6.7 \mu \mathrm{m}$. The thermally-enhanced effect of oxide dissolution by the electrolyte is most pronounced in the near-surface region. Therefore, the mechanical properties of the outer region, near the oxide surface, are known to differ from the corresponding properties in the bulk of the coatings [28]. In addition, higher driving force accelerates the reactions at the substrate/oxide interface and consequently leads to formation of the defects. These local effects are expected to decrease the microhardness of the coatings. The average microhardness value for the coatings on aluminium was $304.66 \mathrm{HV}$, which is approximately eight times higher than the microhardness value $(40.48 \mathrm{HV})$ of the as received aluminium (unanodized). In general, the increase in the microhardness of the coatings is attributed to the nanocrystallite size. The XRD data clearly showed that the crystallite size of the coatings decreased with incorporation of silica in the coating which is explained later. It is known that the nanocrystallite size of the coating (i) hinders the generation of dislocations (ii) prevents crack propagation and (iii) suppresses grain boundary sliding. These three factors result in an improvement of mechanical properties of the coatings.

According to Zergoug et al. [27], the hardness is inversely proportional to the grain size. The large
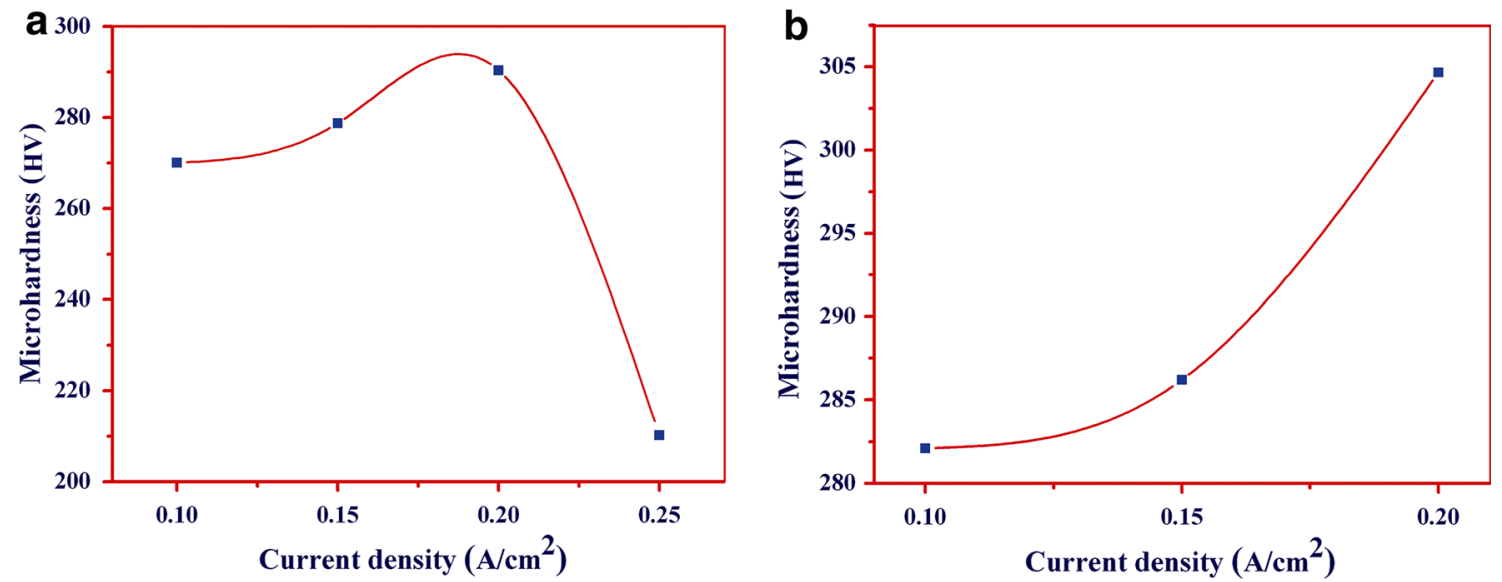

Fig. 2 Influence of current density on microhardness of the coatings obtained from lithium sulphate a, lithium sulphate-sodium silicate $\mathbf{b}$ baths 
variations of the residual indentation depths show their distinctions in the material's ability against deformation. From Zergoug's observations, the microhardness reported here is also due to nanocrystallite size described in XRD section. This kind of depth effect is usually called the indentation size effect [29]. Since, the coating porosity, as well as variations in the grain size depends on the current density, they are accordingly larger at high current density, which would affect the hardness distribution [30].

\subsubsection{Surface Morphological Analysis (SEM and AFM Analysis)}

Figure 3 shows the FESEM images of the coatings corresponding each of the various current densities. FESEM images illustrating the surface morphology of the coatings formed on aluminium from lithium sulphate and lithium sulphate-sodium silicate baths by anodization at various current densities $\left(0.1-0.25 \mathrm{~A} / \mathrm{cm}^{2}\right)$ are presented in Figs. 3 and 4 . It is clearly seen from the Fig. 3 that the coatings formed in lithium sulphate bath had quite different surface morphologies from that in lithium sulphate-sodium silicate bath by varying current density. From the Fig. 4, it can be observed that there are definite changes in surface structures in terms of porous nature, crack behaviour and compact nature. Figure $3 \mathrm{~b}$ clearly shows the coating with more porous nature was formed at $0.15 \mathrm{~A} / \mathrm{cm}^{2}$ (lithium sulphate bath), while Fig. 3d show that as more number of cracks. But this case is less pronounced in other cases like Fig. 3c. All the coatings were relatively dense with the majority of pores and cracks located near the coating surface, possibly as a result of thermal stresses during the growth of the coatings. On visualizing the microscopic images in both baths (lithium sulphate and lithium sulphate-sodium silicate baths), many chimps and holes can be seen on the top surface of the coatings. The coating surface is composed of various sizes of fine grains, which are coordinated themselves and unevenly distributed on the surface, as well as extended cracks, can be seen on the surface.

The microstructure of the coatings is made up of a relative thin barrier layer at the interface and an outer porous layer with ideally cylindrical pores [31]. On the other hand, the porous layer thicknesses are proportional to the charge passed during anodizing at a particular area. Some microcracks are apparent on the surface (Fig. 4a). There are also
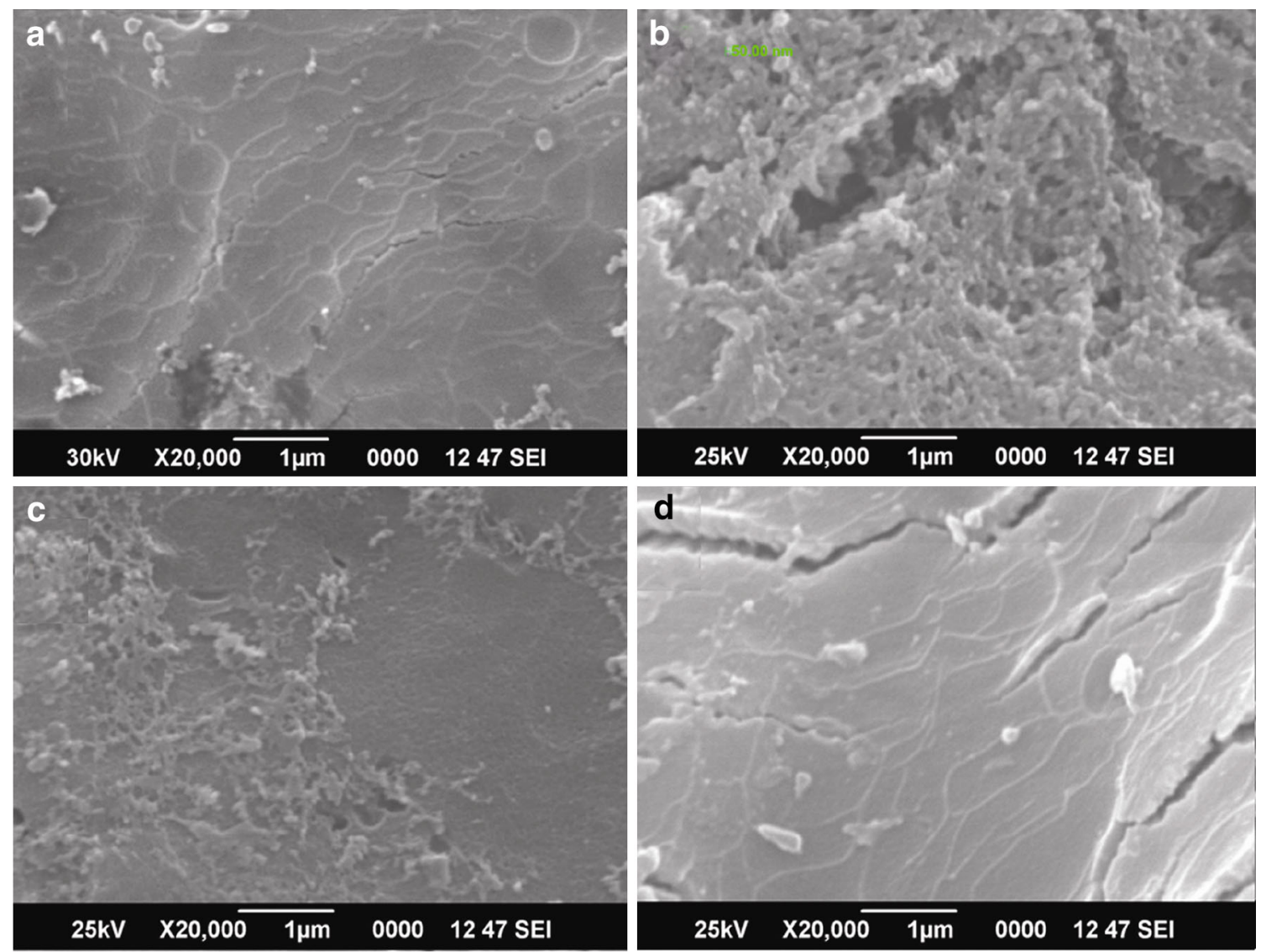

Fig. 3 SEM images of the coatings formed on aluminium from lithium sulphate bath by anodization at various current densities: a $0.1 \mathrm{~A} / \mathrm{cm}^{2}$, b $0.15 \mathrm{~A} / \mathrm{cm}^{2}$, c $0.2 \mathrm{~A} / \mathrm{cm}^{2}$, d $0.25 \mathrm{~A} / \mathrm{cm}^{2}$ 


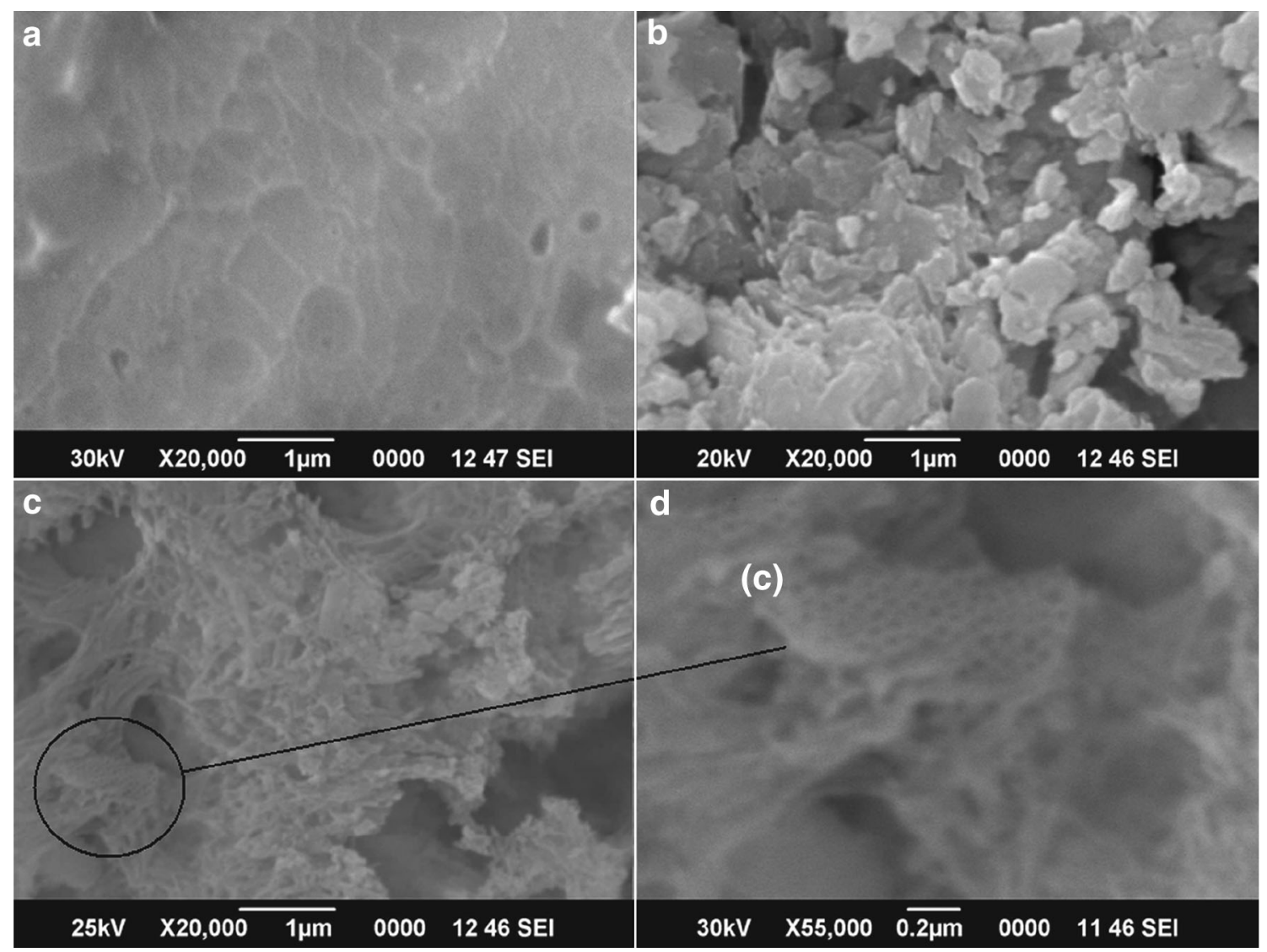

Fig. 4 SEM images of the coatings formed on aluminium from lithium sulphate-sodium silicate bath by anodization at various current densities: a $0.1 \mathrm{~A} / \mathrm{cm}^{2}$, b $0.15 \mathrm{~A} / \mathrm{cm}^{2}, \mathbf{c} 0.2 \mathrm{~A} / \mathrm{cm}^{2}, \mathbf{d}$ the focused view of the circle in $\mathbf{c}$

some debris and many small holes on these areas. The bean cake-shaped "volcanic craters" (Fig. 4b) are more clear. Only the coatings obtained from lithium sulphate-sodium silicate bath at $0.2 \mathrm{~A} / \mathrm{cm}^{2}$ have smooth honey comp structure which is interesting as shown in focused view (Fig. 4d).

The pores with various shapes were seen to be distributed all over the surface of the coatings can be clearly seen from the FESEM investigation (lithium sulphate-sodium silicate bath). It should also be noted that there were cracks on the surface of the coatings that were formed due to the thermal stress during anodization process. The surface topography of the coatings obtained from lithium sulphate electrolyte for $30 \mathrm{~min}$ at various current densities was investigated using AFM which is presented in Fig. 5, showing different grains, as well as pores size and structure with current density. This observation has been reported by numerous investigators in earlier literature [32].

The statistical parameters (mean distribution, average roughness and root mean square roughness) of the coatings were measured using NOVA image processing software which is given in Table 1. From that, one can ascertain that all the parameters are increasing with current density except in the case of $0.2 \mathrm{~A} / \mathrm{cm}^{2}$. In addition to this, pore analysis was also done for the coatings fabricated at various current densities which are shown in Fig. 5. From that, the number of pores is decreasing with current density up to $0.15 \mathrm{~A} / \mathrm{cm}^{2}$, after that, it decreases. Again, the number of pores increased to significant extent when the current density was $0.25 \mathrm{~A} / \mathrm{cm}^{2}$. It was also apparent that the number of pores was decreasing, while the diameter of the pores was apparently increasing with prolonged time.

The morphological changes (Fig. 5) in the coatings formed on aluminium at various current densities (0.1-0.2 A/ $\mathrm{cm}^{2}$ ) were monitored using AFM. From Fig. 6, it is observed that the coatings formed at $0.2 \mathrm{~A} / \mathrm{cm}^{2}$ having lesser number of pores. The area, diameter and length of the pores are decreasing with the increasing current density. Since the coatings formed above $0.2 \mathrm{~A} / \mathrm{cm}^{2}$ is rough and coarse structure, it is omitted here. From this, one can ascertain that the minimum numbers of the pores are formed in the coatings at $0.2 \mathrm{~A} / \mathrm{cm}^{2}$.

\subsubsection{Elemental Analysis (EDS)}

The elemental composition of the coatings obtained at various current densities $\left(0.1-0.25 \mathrm{~A} / \mathrm{cm}^{2}\right)$ was investigated by EDS for both lithium sulphate and lithium 

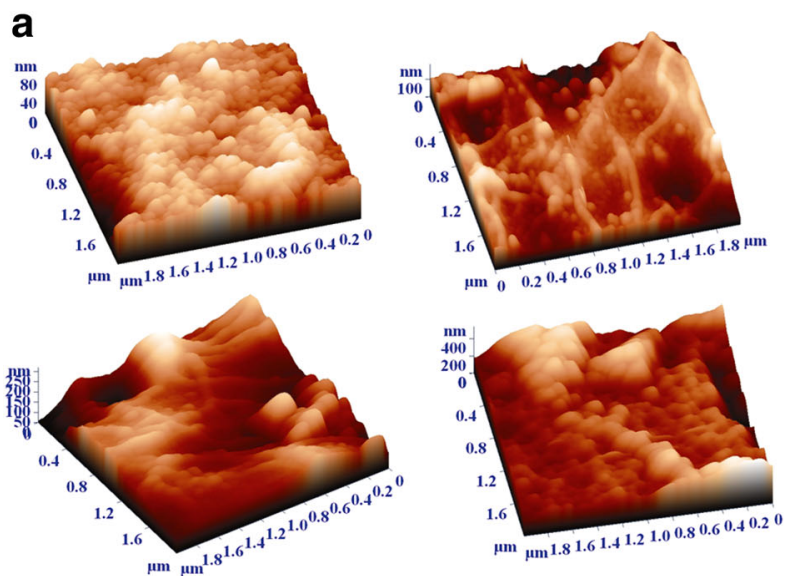

b
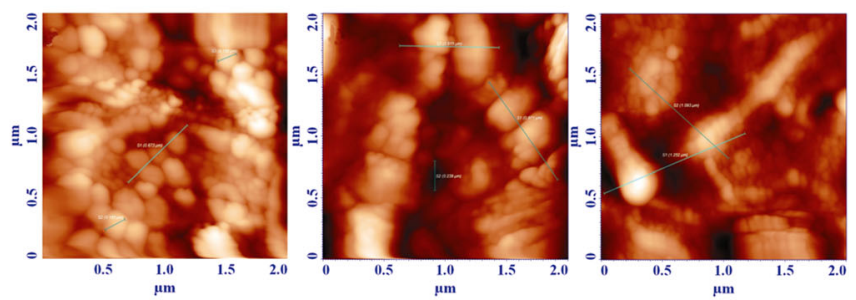

Fig. 5 Influence of current density on microstructure (using atomic force microscope) of the coatings obtained from lithium sulphate a, lithium sulphate-sodium silicate $\mathbf{b}$ baths

sulphate-sodium silicate baths (Table 2). In both cases the oxygen content increases up to a certain extent, thereafter it decreases with the increasing current density, but for the aluminium, it follows in a reverse trend. From Table 2, oxygen and sulphur contents are increasing up to 0.2 $\mathrm{A} / \mathrm{cm}^{2}$, after that, the values get decreased. From this, one can ascertain that the coating is mainly composed of the oxygen and silicon from the electrolyte and aluminium from the substrate. Some minor differences in contrast, due to local variations in composition, are evident in the layers of the coating material of about $2 \mathrm{~nm}$ thickness close to the metal/coating interface. Tran et al. [30] using an IR technique, have reported that the sulphur is present as the anion, whereas Liechti et al. [12] found that the sulphur is present as a basic sulphate which is involved in the dissolution process in the pores. In the case of lithium sulphate-sodium silicate bath, lesser amount of $\mathrm{Si}$ also present in the coating. Hence the coating is mainly composed of alumina and silica phases. Abundant presence of elements derived from the electrolyte also indicated that the composition of the coating can be changed by adjusting the constituents and concentration of the electrolyte and additive.

\subsubsection{Phase and Structural Analysis (XRD)}

Figure 7 shows the XRD pattern of the coatings obtained at various current densities $\left(0.1-0.25 \mathrm{~A} / \mathrm{cm}^{2}\right)$ in lithium sulphate and lithium sulphate-sodium silicate bathes. From Fig. 7a, it can be observed that there is no sharp peaks in the pattern of the coatings formed at $0.1 \mathrm{~A} / \mathrm{cm}^{2}$, but some traces of $\delta$ alumina appear at $80.417^{\circ}$ with preferred orientation of (4 26$)$ and $\alpha$ alumina appears at $111.078^{\circ}$ with preferred orientation of $\left(\begin{array}{lll}3 & 1 & 8\end{array}\right)$ in the coatings formed at $0.15 \mathrm{~A} / \mathrm{cm}^{2}$. The coatings formed at $0.2 \mathrm{~A} / \mathrm{cm}^{2}$ show different behaviour from 0.1 and $0.15 \mathrm{~A} / \mathrm{cm}^{2}$. In that pattern, sharp peaks are seen and $\gamma / \delta$ alumina phases are predominant. $\gamma$ alumina is appearing at $39.693^{\circ}(d=2.2716)$ in the preferred orientation of $\left(\begin{array}{lll}2 & 2 & 2\end{array}\right)$ and $\delta$ alumina peak appears at $44.539^{\circ}(d=2.0365)$ in the preferred orientation of (2 08 ), along with some traces of $\alpha$ alumina. Depending upon the anodizing conditions, the coatings may be either amorphous, crystalline, or a mixture. The degree of crystallinity of the coatings generally increases with the decreasing current density and increasing voltage [33].

Amorphous content increased with the applied current density in the case of lithium sulphate but, which is reverse in lithium sulphate-sodium silicate bath. When we increase the current density to $0.25 \mathrm{~A} / \mathrm{cm}^{2}$, the crystallinity of the coatings is decreased and some traces of $\alpha$ and $\delta$ alumina phases are formed which are shown in Fig. 7a. Since the top surface of the coating is a place where new oxide continuously forms, there must be a growth product rather than a transformation product formed by the crystallization of the existing amorphous $\mathrm{Al}_{2} \mathrm{O}_{3}$, layer [34].

It may be concluded that in general, nonporous films are regarded as amorphous and porous coatings as crystalline or both. The works of Refs. [30], [35] and [36] are also relevant in this aspect. The presence of water was referred by some workers [37] as a necessity to exert a stabilizing effect on the spinal-type structure of alumina. The crystallite size of the coatings formed at various current density was also calculated which ranges from 17 to $66 \mathrm{~nm}$.

On the other hand, XRD measurements have been performed for the coatings obtained from lithium sulphatesodium silicate bath to determine the nature of the alumina and silica compounds. Figure $7 \mathrm{~b}$ shows the XRD pattern of the coatings obtained from lithium sulphate-sodium silicate bath at various current densities $\left(0.1-0.2 \mathrm{~A} / \mathrm{cm}^{2}\right)$. There are no significant sharp peaks when the current density was maintained as $0.1 \mathrm{~A} / \mathrm{cm}^{2}$ except some traces of 
Table 1 Influence of current density on surface statistics of the coatings obtained from lithium sulphate bath at $(10 \pm 1){ }^{\circ} \mathrm{C}$ for 30 min

\begin{tabular}{|c|c|c|c|c|c|c|}
\hline \multirow{2}{*}{$\begin{array}{l}\text { Current } \\
\text { density } \\
\left(\mathrm{A} / \mathrm{cm}^{2}\right)\end{array}$} & \multicolumn{2}{|c|}{ Mean distribution (nm) } & \multicolumn{2}{|c|}{ Average roughness $(\mathrm{nm})$} & \multicolumn{2}{|c|}{ Root means square roughness } \\
\hline & $\begin{array}{l}\text { Lithium } \\
\text { sulphate }\end{array}$ & $\begin{array}{l}\text { Lithium sulphate- } \\
\text { sodium silicate }\end{array}$ & $\begin{array}{l}\text { Lithium } \\
\text { sulphate }\end{array}$ & $\begin{array}{l}\text { Lithium sulphate- } \\
\text { sodium silicate }\end{array}$ & $\begin{array}{l}\text { Lithium } \\
\text { sulphate }\end{array}$ & $\begin{array}{l}\text { Lithium sulphate- } \\
\text { sodium silicate }\end{array}$ \\
\hline 0.10 & 309.26 & 117.32 & 46.18 & 29.05 & 58.42 & 36.15 \\
\hline 0.15 & 417.27 & 93.10 & 136.58 & 18.78 & 168.92 & 24.56 \\
\hline 0.20 & 103.57 & 80.25 & 8.89 & 12.88 & 12.56 & 16.78 \\
\hline 0.25 & 857.43 & - & 289.76 & - & 329.02 & - \\
\hline
\end{tabular}

a
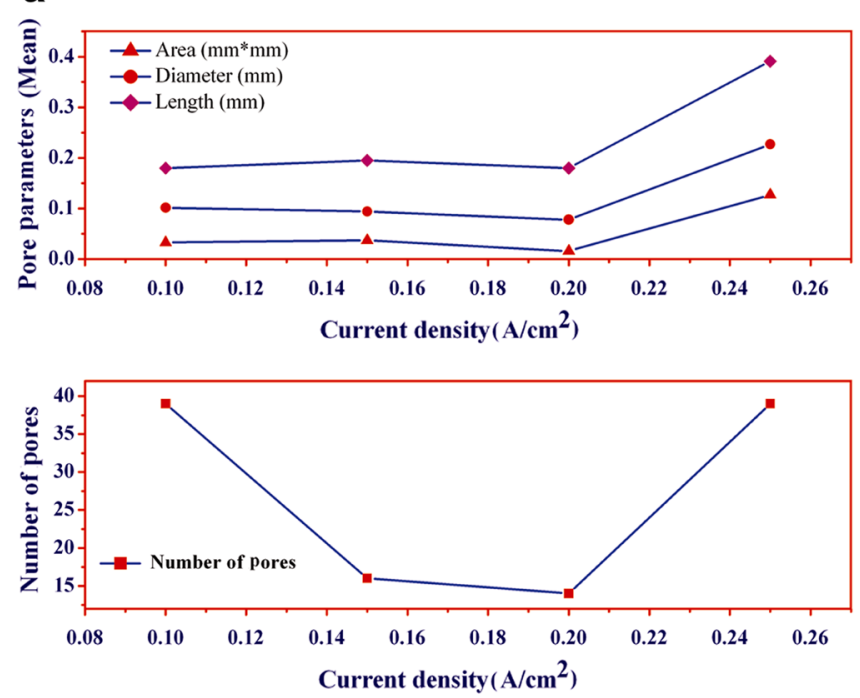

b
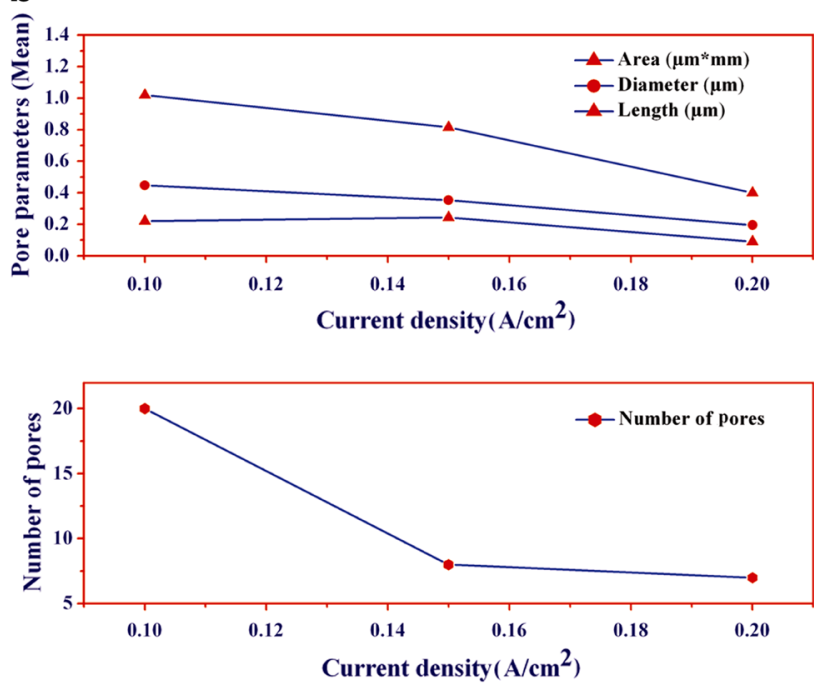

Fig. 6 Influence of current density on pore parameters (number of pores, area, diameter and length of the pores) of the coatings obtained from lithium sulphate a, lithium sulphate-sodium silicate $\mathbf{b}$ baths

zeolite, $\alpha$-alumina and mullite phases which are shown in Fig. 7b. When the current density was maintained at $0.15 \mathrm{~A} / \mathrm{cm}^{2}$, zeolite still appears at $44.831^{\circ}(d=2.0124)$ with the preferred orientation of (11 51 ) as a major phase. In addition to this, $\alpha$ alumina appears at $41.6826^{\circ}$ $(d=2.1658)$ and $43.364^{\circ}(d=2.0877)$ with the preferred orientations of $\left(\begin{array}{lll}0 & 0 & 6\end{array}\right)$ and (lll $\left.\begin{array}{lll}1 & 1 & 3\end{array}\right)$, respectively. The crystalline nature increased with the existence of some traces of mullite and $\alpha$ alumina phases.

In this case, several major phases ( $\delta$ alumina, mullite and $\alpha$ alumina) are observed in the coatings formed in lithium sulphate-sodium silicate bath at $0.2 \mathrm{~A} / \mathrm{cm}^{2} . \delta$ alumina phase appears at $19.424^{\circ}(d=4.5679)$ with the orientation of $\left(\begin{array}{lll}1 & 0 & 3\end{array}\right)$. The zeolite appears at $44.837^{\circ}$ ( $d=2.0125$ ) with the preferred orientation of (11 51 ). In addition to this, mullite phase appears at $65.407^{\circ}$ $(d=1.4255)$ and $78.726^{\circ}(d=1.2171)$ with the preferred orientations of (2 50 ) and (2 60 ), respectively. Finally, $\alpha$ alumina appears at $98.403^{\circ}(d=1.0110)$ and $101.084^{\circ}$ ( $d=0.9970)$ with the preferred orientations of (0 42 ) and
(2 1 10), respectively. The crystallite size of the coatings was calculated that it ranges from 10 to $63 \mathrm{~nm}$.

Literature [26] studied the effect of the current density on the phase composition of ceramic coatings. They found that the relative $\alpha$ and $\gamma \mathrm{Al}_{2} \mathrm{O}_{3}$ content are high, when the current density was greater than $10 \mathrm{~A} / \mathrm{dm}^{2}$, and almost low when the current density is less than $10 \mathrm{~A} / \mathrm{dm}^{2}$. Further crystalline alumina has higher resistivity than the amorphous alumina, and the presence of a higher resistivity oxide above a lower resistivity oxide can lead to fingers of the latter oxide penetrating the outer oxide eventually to short-circuit [38].

\subsubsection{Evaluation of Corrosion Resistance Behaviour}

Corrosion resistance behaviour of the coatings obtained at various current densities $\left(0.1-0.25 \mathrm{~A} / \mathrm{cm}^{2}\right)$ was evaluated by Tafel polarization studies at room temperature $\left[(28 \pm 1){ }^{\circ} \mathrm{C}\right]$ using $3.5 \% \mathrm{NaCl}$ as electrolyte using electrochemical workstation and the polarization curves are 
Table 2 Influence of current density on elemental composition (at.\%) of the coatings obtained at $(10 \pm 1){ }^{\circ} \mathrm{C}$ for $30 \mathrm{~min}$ in lithium sulphate and lithium sulphate-sodium silicate baths

\begin{tabular}{llll}
\hline $\begin{array}{l}\text { Current } \\
\text { density } \\
\left(\mathrm{A} / \mathrm{cm}^{2}\right)\end{array}$ & Element & $\begin{array}{l}\text { Lithium } \\
\text { sulphate } \\
\text { bath (at.\%) }\end{array}$ & $\begin{array}{l}\text { Lithium sulphate- } \\
\text { sodium silicate } \\
\text { bath (at.\%) }\end{array}$ \\
\hline 0.10 & $\mathrm{O}$ & 72.57 & 72.40 \\
& $\mathrm{Al}$ & 23.58 & 22.73 \\
& $\mathrm{~S}$ & 3.86 & 3.32 \\
0.15 & $\mathrm{Si}$ & - & 1.54 \\
& $\mathrm{O}$ & 72.63 & 72.82 \\
& $\mathrm{Al}$ & 23.27 & 21.67 \\
& $\mathrm{~S}$ & 4.10 & 3.50 \\
0.20 & $\mathrm{Si}$ & & 2.00 \\
& $\mathrm{O}$ & 73.34 & 74.46 \\
& $\mathrm{Al}$ & 22.41 & 21.00 \\
& $\mathrm{~S}$ & 4.25 & 4.43 \\
0.25 & $\mathrm{Si}$ & & 0.10 \\
& $\mathrm{O}$ & 72.20 & - \\
& $\mathrm{Al}$ & 23.95 & - \\
\hline
\end{tabular}

presented in Fig. 8. From the data given in Table 3, corrosion rate $\left(R_{\text {corr }}\right)$ and corrosion current density $\left(I_{\text {corr }}\right)$ is directly proportional to each other. Then, the lowest corrosion current density $\left(7.96 \times 10^{-11} \mathrm{~mA}\right)$ and corrosion rate $\left(3.41 \times 10^{-2}\right.$ mile/year $)$ were obtained for the coatings formed at $0.2 \mathrm{~A} / \mathrm{cm}^{2}\left[(10 \pm 1){ }^{\circ} \mathrm{C}, 30 \mathrm{~min}\right]$. Since, the corrosion resistance performance may depends upon the number of the pores and their sizes, the coatings obtained at $0.2 \mathrm{~A} / \mathrm{cm}^{2}$ have (Fig. 8) minimum number of pores and hence exhibited better corrosion resistance.
Figure 8 shows the polarization curves recorded in $3.5 \%$ $\mathrm{NaCl}$ solution using three-electrode system for the coatings formed at various current densities $\left(0.1-0.2 \mathrm{~A} / \mathrm{cm}^{2}\right)$. The coatings formed at various current density show increased corrosion performance compared to that of $\mathrm{Al}$ substrate. The coating formed at $0.2 \mathrm{~A} / \mathrm{cm}^{2}$ has the highest positive corrosion potential $(743 \mathrm{mV})$ obtained from the coatings fabricated from lithium sulphate-sodium silicate bath, while the coating formed at $0.1 \mathrm{~A} / \mathrm{cm}^{2}$ has the least corrosion potential $(630 \mathrm{mV})$ in the same bath solution. The corrosion current of the oxide coating changed from $3.67 \times 10^{-10}$ to $7.79 \times 10^{-11} \mathrm{~mA}$. According to the Fig. 8, it is clearly seen that the corrosion rate of $3.343 \times 10^{-2}$ (mile/year) for the coating formed at 0.2 $\mathrm{A} / \mathrm{cm}^{2}$ is minimum, when compared to that of other coatings and hence $0.2 \mathrm{~A} / \mathrm{cm}^{2}$ is the optimum current density for the formation of coatings with excellent corrosion resistance. From the experiments and data, one can conclude that the addition of sodium silicate with lithium sulphate electrolyte for forming coatings on aluminium can enhance the corrosion resistance up to $3.41 \times 10^{-2}$ mile/ year $\left(R_{\text {corr }}\right)$.

From Table 4, the maximum polarization resistance (660.96 $\Omega$ ) was observed for the coatings formed at 0.2 $\mathrm{A} / \mathrm{cm}^{2}\left[(10 \pm 1){ }^{\circ} \mathrm{C}, 30 \mathrm{~min}\right]$, while the capacitance was $8.98 \mu \mathrm{F}$. Figure 9 shows the comparative EIS curves for the coatings obtained at various current densities in $3.5 \%$ $\mathrm{NaCl}$. The solution resistance $\left(R_{\mathrm{s}}\right)$, polarization resistance $\left(R_{\mathrm{p}}\right)$ and double layer capacitance $\left(C_{\mathrm{dl}}\right)$ values were calculated from the plots and are given in Table 4 . The solution resistance $(\Omega)$ increases with current density $\left(0.1 \mathrm{~A} / \mathrm{cm}^{2}, 9.73 \times 10^{-7} \Omega ; 0.2 \mathrm{~A} / \mathrm{cm}^{2}, 0.05 \Omega\right)$. Table 4 gives that the coatings formed at $0.2 \mathrm{~A} / \mathrm{cm}^{2}$ are more protective than others. This is evident also from the highest
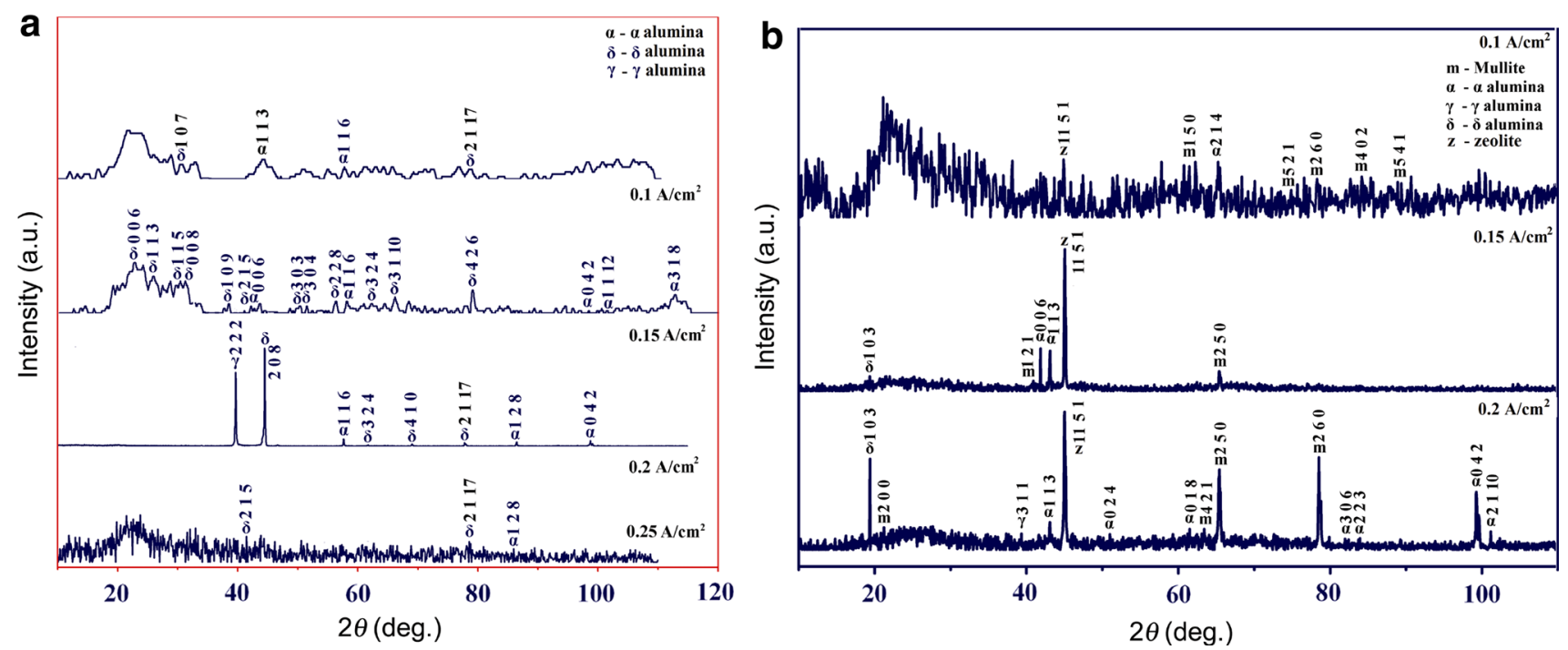

Fig. 7 Influence of the current density on XRD pattern of the coatings obtained from lithium sulphate $\mathbf{a}$, lithium sulphate-sodium silicate $\mathbf{b}$ baths 

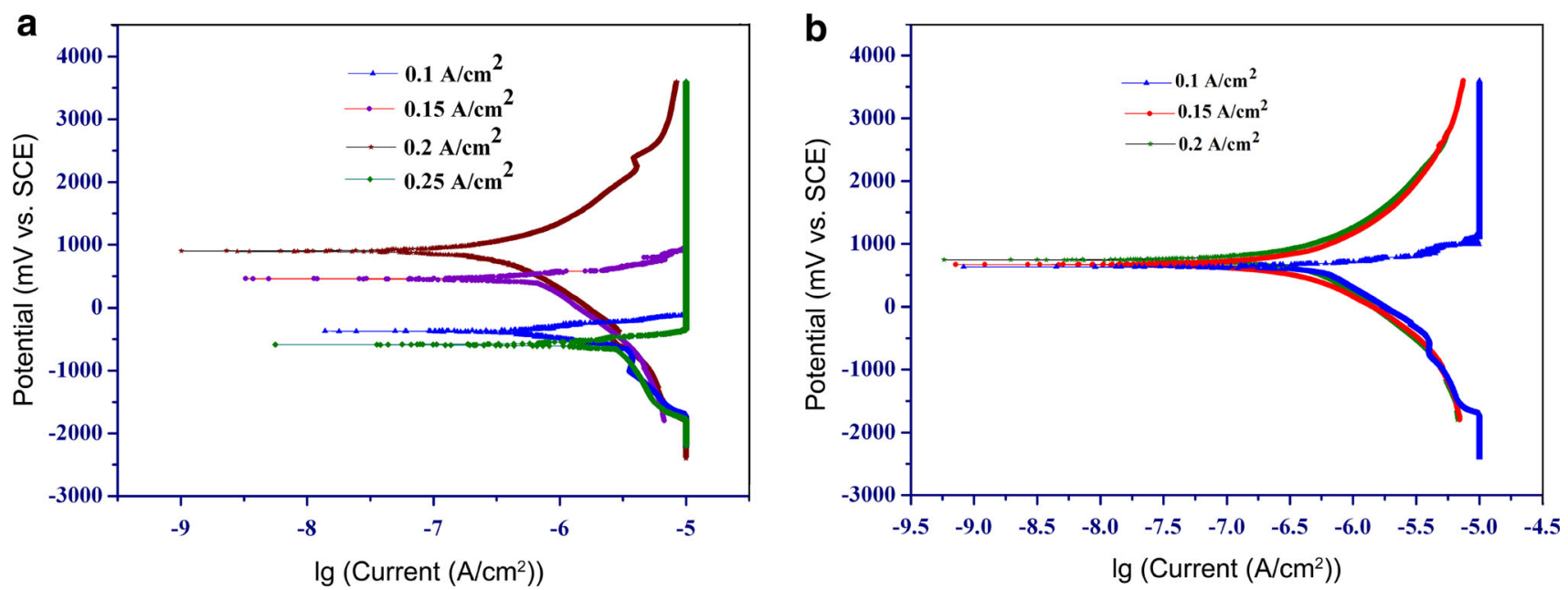

Fig. 8 Influence of current density on corrosion resistance of the coatings using Tafel polarization technique obtained from lithium sulphate a, lithium sulphate-sodium silicate b baths

Table 3 Calculated Tafel polarization parameters for the coatings formed from lithium sulphate bath at various current densities

\begin{tabular}{|c|c|c|c|c|c|c|}
\hline \multirow[t]{2}{*}{ Current density $\left(\mathrm{A} / \mathrm{cm}^{2}\right)$} & \multicolumn{2}{|l|}{$I_{\text {corr }}(\mathrm{mA})$} & \multicolumn{2}{|c|}{$E_{\text {corr }}(\mathrm{mV} v s . \mathrm{SCE})$} & \multicolumn{2}{|l|}{$R_{\text {corr }}($ mile/year $)$} \\
\hline & Lithium sulphate & $\begin{array}{l}\text { Lithium sulphate- } \\
\text { sodium silicate }\end{array}$ & Lithium sulphate & $\begin{array}{l}\text { Lithium sulphate- } \\
\text { sodium silicate }\end{array}$ & Lithium sulphate & $\begin{array}{l}\text { Lithium sulphate- } \\
\text { sodium silicate }\end{array}$ \\
\hline 0.10 & $1.08 \times 10^{-9}$ & $3.67 \times 10^{-10}$ & -374 & 630 & $4.65 \times 10^{-1}$ & $1.57 \times 10^{-1}$ \\
\hline 0.15 & $7.59 \times 10^{-10}$ & $8.15 \times 10^{-11}$ & 460 & 667 & $3.25 \times 10^{-1}$ & $3.49 \times 10^{-2}$ \\
\hline 0.20 & $7.96 \times 10^{-11}$ & $7.79 \times 10^{-11}$ & 900 & 743 & $3.41 \times 10^{-2}$ & $3.34 \times 10^{-2}$ \\
\hline 0.25 & $1.75 \times 10^{-9}$ & - & -588 & - & $7.53 \times 10^{-1}$ & - \\
\hline
\end{tabular}

Table 4 Influence of current density on impedance parameters of the coatings obtained from lithium sulphate bath at $(10 \pm 1){ }^{\circ} \mathrm{C}$ for 30 min

\begin{tabular}{|c|c|c|c|c|c|c|}
\hline \multirow{2}{*}{$\begin{array}{l}\text { Current } \\
\text { density } \\
\left(\mathrm{A} / \mathrm{cm}^{2}\right)\end{array}$} & \multicolumn{2}{|l|}{$R_{\mathrm{s}}(\Omega)$} & \multicolumn{2}{|l|}{$C_{\mathrm{dl}}(\mu \mathrm{F})$} & \multicolumn{2}{|l|}{$R_{\mathrm{p}}$} \\
\hline & $\begin{array}{l}\text { Lithium } \\
\text { sulphate bath }\end{array}$ & $\begin{array}{l}\text { Lithium sulphate- } \\
\text { sodium silicate bath }\end{array}$ & $\begin{array}{l}\text { Lithium } \\
\text { sulphate bath }\end{array}$ & $\begin{array}{l}\text { Lithium sulphate- } \\
\text { sodium silicate bath }\end{array}$ & $\begin{array}{l}\text { Lithium } \\
\text { sulphate } \\
\text { bath }(\Omega)\end{array}$ & $\begin{array}{l}\text { Lithium sulphate- } \\
\text { sodium silicate } \\
\text { bath }(\mathrm{k} \Omega)\end{array}$ \\
\hline 0.10 & $2.9 \times 10^{-3}$ & $9.73 \times 10^{-7}$ & 54.35 & 32.24 & 433.59 & 1,320 \\
\hline 0.15 & 0.22 & $5.45 \times 10^{-6}$ & 21.31 & 23.66 & 454.50 & 1,770 \\
\hline 0.20 & 0.57 & 0.05 & 8.98 & 11.73 & 660.96 & 3,120 \\
\hline 0.25 & $1.24 \times 10^{-7}$ & - & 36.95 & - & 4.52 & - \\
\hline
\end{tabular}

polarization resistance of the coating formed at a 0.2 $\mathrm{A} / \mathrm{cm}^{2}(3.12 \mathrm{k} \Omega)$.

\section{Conclusions}

Ceramic nanocomposite coating was successfully fabricated on aluminium in lithium sulphate and lithium sulphate-sodium silicate bathes to reduce huge processing cost. Both microhardness test (304.66 HV) and corrosion resistance performance (Tafel polarization and AC impedance) showed that the coating could significantly improve the corrosion resistance of aluminium by the addition of sodium silicate $\left(R_{\mathrm{p}}\right.$ is $660.96 \Omega$ and $3.12 \mathrm{k} \Omega$ in lithium sulphate and lithium sulphate-sodium silicate bathes, respectively). Our results highlight the important influence of the anodization parameters, especially the current density on the microstructure and mechanical testing evaluation of the ceramic coatings. From the experiments and results, it was observed that the addition of sodium silicate would increase the hardness and corrosion resistance of aluminium. Although this effect has been explained with other electrolytes in the past literature, the usage of the sodium silicate with the lithium sulphate will 

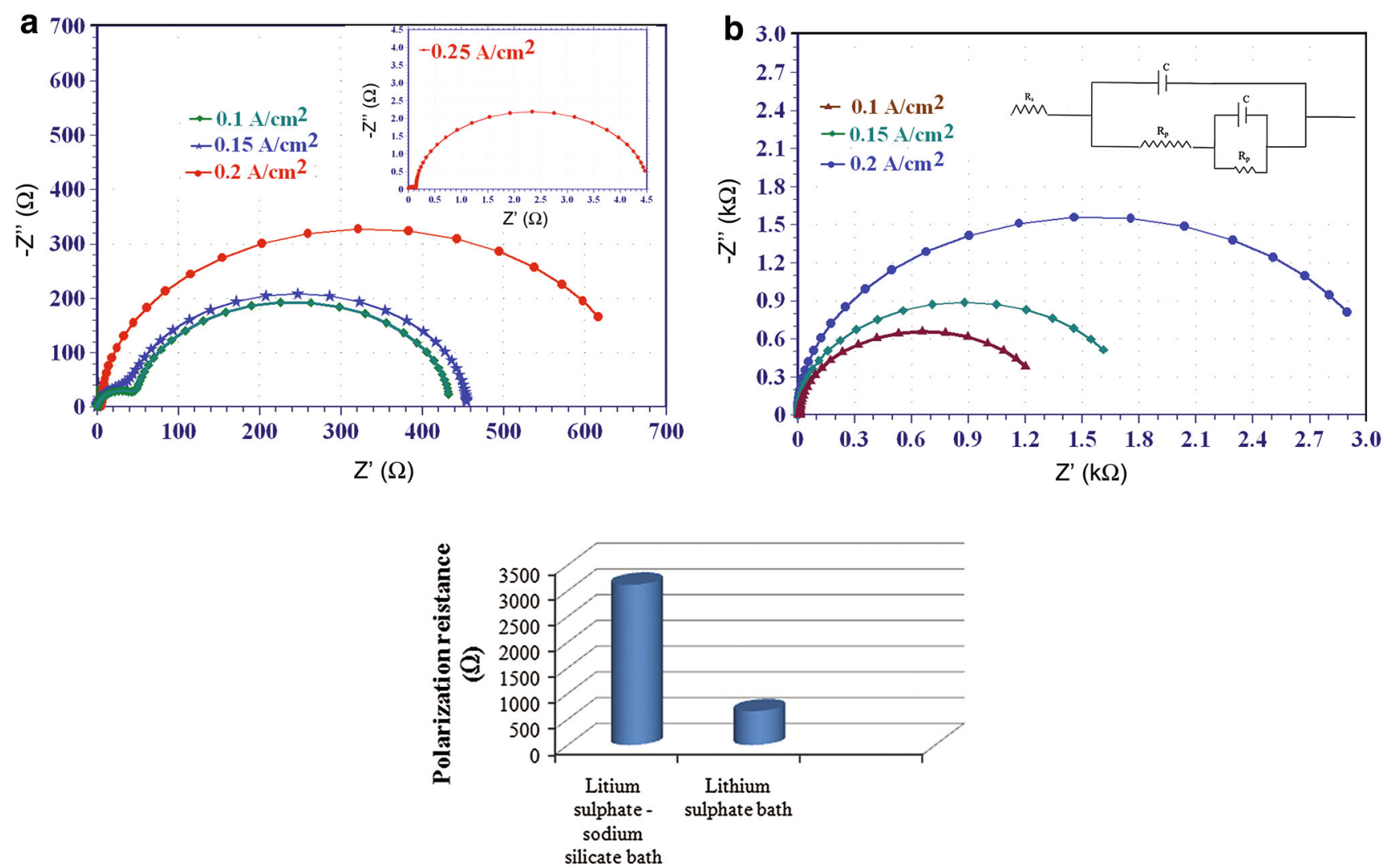

Fig. 9 Influence of current density on corrosion resistance of the coatings (Nyquist plots) obtained from lithium sulphate a, lithium sulphatesodium silicate b baths

open a new door in the field of anodization to fabricate thick and hard coatings. A potential way established here to reduce the pores and to improve the corrosion performance in aggressive environments would increase the commercial value in the near future.

Acknowledgments One of the authors (M. Mubarak Ali) would like to acknowledge the Council of Scientific and Industrial Research, New Delhi for awarding CSIR-SRF (senior research fellow ship-09/ 810 (0011) 2010 EMR) and also gratefully acknowledge the UGCCSR consortium, Indore and UGC networking facility, School of Chemistry, University of Hyderabad, India for providing the necessary instrumental facilities.

\section{References}

[1] T.S. Eyre, in Treatise on Materials Science and Technology, vol. 13, ed. by D. Scott (Academic Press, New York, 1979), pp. 363-365

[2] J. Patscheider, T. Zehnder, M. Diserens, Surf. Coat. Technol. 146-147, 201 (2001)

[3] D.M. Cao, T. Wang, B. Feng, W.J. Meng, K.W. Kelly, Thin Solid Films 398-399, 553 (2001)

[4] X.H. Yang, T.J. Schmidt, W. Shan, J.J. Song, B. Goldenberg, Appl. Phys. Lett. 66, 1 (1995)

[5] A.A. Voevodin, J.S. Zabinski, Thin Solid Films 370, 223 (2000)
[6] E.W. Lee, T. Oppenheim, K. Robinson, B. Aridkahari, N. Neylan, D. Gebreyesus, M. Richardson, M. Arzate, C. Bove, M. Iskandar, C. Sanchez, E. Toss, I. Martinez, D. Arenas, J. Ogren, J. Mclennan, R. Clark, W.E. Frazier, O.S. Es-Said, Eng. Fail. Anal. 14, 1538 (2007)

[7] L. Pedersen, L. Arnberg, Metall. Mater. Trans. A 32, 525 (2001)

[8] S. Wernick, R. Pinner, P.G. Sheasby, The Surface Treatment and Finishing of Aluminum and its Alloys, vol. 1-2, 5th edn. (Finishing Publications Ltd., Teddington, Middlesex, 1987), pp. 148-149

[9] M. Mubarak Ali, V. Raj, Trans. Inst. Metal. Finish. 90, 215 (2012)

[10] M. Mubarak Ali, V. Raj, J. Mater. Sci. Technol. 29, 595 (2013)

[11] V. Raj, M. Mubarak Ali, J. Mater. Proces. Technol. 209, 5341 (2009)

[12] F. Liechti, W.D. Treadwell, Helu. Chem. Acta 30, 1204 (1947)

[13] M.R. Sridhar, M.M. Yovanovich, Wear 193, 91 (1996)

[14] V.K. Williamgrips, V. Ezhilselvi, H.C. Barshilia, K.S. Rajam, Electrochem. Acta 51, 3461 (2006)

[15] A. Feldman, E.N. Farabough, W.K. Haller, D.M. Sanders, R.A. Stempniak, J. Vac. Sci. Technol. A 4, 2969 (1986)

[16] B.Y. Long, H.H. Wu, B.H. Long, J. Jilin, Univ. (Sci. Ed.) 43, 68 (2005) (in Chinese)

[17] H.H. Wu, X.Y. Lu, B.H. Long, X. Wang, J. Wang, Z. Jin, Mater. Lett. 59, 370 (2005)

[18] L. Arurault, Trans. Inst. Met. Finish. 86, 51 (2008)

[19] G.E. Thompson, R.C. Furneaux, G.C. Wood, J.A. Richardson, J.S. Goode, Nature 272, 433 (1978)

[20] R. Mahn, Plat. Surf. Finish. 75, 35 (1988) 
[21] H. Wu, J. Wang, B. Long, B. Long, Z. Jin, W. Naidan, F. Yu, D. Bi, Appl. Surf. Sci. 252, 1545 (2005)

[22] D.F. McLennan, Corrosion 17, 283 (1959)

[23] F. Li, L. Zhang, R.M. Metzger, Chem. Mater. 10, 2470 (1998)

[24] V. Parkhutik, J.M. Albella, J.M. Martinez-Duart, in Modern Aspects of Electrochemistry, 1st edn., ed. by B.E. Conway (Plenum Press, New York, 1992), pp. 88-89

[25] R.B. Mason, J. Elecrochem, Soc. 102, 671 (1955)

[26] G.L. Yang, X.Y. Lu, Y.Z. Bai, H.F. Cui, Z.S. Jin, J. Alloys Compds. 345, 196 (2002)

[27] M. Zergoug, S. Lebaili, H. Boudjellal, A. Benchaala, Nondestruct. Test. Eval. Int. 37, 65 (2004)

[28] B.A. Scott, Trans. Inst. Met. Finish. 43, 1 (1965)

[29] W.C. Oliver, G.M. Pharr, J. Mater. Res. 7, 1564 (1992)
[30] T. Lantran, F. Naudin, P. Robbe-Bourget, J. Phys. (Paris) 25, 11 (1964)

[31] F. Keller, M.S. Huntey, D.L. Robinson, J. Electrochem. Soc. 100, 411 (1953)

[32] K. Kobayashi, K. Shimizu, J. Electrochem. Soc. 135, 908 (1988)

[33] C.T. Chen, G.A. Hutchins, J. Electrochem. Soc. 132, 1567 (1985)

[34] R.L. Chid, P.H. Chang, C.H. Tung, Thin Solid Films 260, 47 (1995)

[35] E. Lichtenberger, Zh. Prikl, Khim. 34, 1286 (1961)

[36] V.P. Pavelkina, A.F. Bogoyavlenskii, Zh. Prikl, Khim. 37, 819 (1964)

[37] W.G. Burgers, A. Classen, J. Zernicke, Z. Phys. 74, 593 (1932)

[38] P. Skeldon, K. Shimizu, G.E. Thompson, G.C. Wood, Philos. Mag. B 61, 927 (1989) 